\title{
EFL students' vocabulary learning strategies and their affixes knowledge
}

\author{
Eko Noprianto $^{\text {a* }}$ (D), Pupung Purnawarman ${ }^{b}$ (iD \\ ${ }^{a}$ Universitas Pendidikan Indonesia, 44 Telogorejo, Lampung Timur 34381, Indonesia \\ ${ }^{b}$ Universitas Pendidikan Indonesia, Bandung, Indonesia
}

\section{APA Citation:}

Noprianto, E., \& Purnawarman, P. (2019). EFL students' vocabulary learning strategies and their affixes knowledge. Journal of Language and Linguistic Studies, 15(1), 262-275.

Submission Date:01/03/2018

Acceptance Date:03/07/2018

\begin{abstract}
Vocabulary Learning Strategies and knowledge of affixes have long been considered to have influence on learners' vocabulary learning. However, how they relate to each other seems to have drawn little attention. This current study was intended to explore the frequency of vocabulary learning strategies used by Indonesian high school students, to find out their knowledge of affixes as well as to figure out how their reported vocabulary learning strategies use relate to their knowledge of affixes. This correlational study involved 116 participants of the first grade of senior high school consisting of 27 males and 89 females aged between fourteen and seventeen years old. A questionnaire of Vocabulary Learning Strategies adapted from Schmitt (1997) and a Word Part Level Test proposed by Sasao \& Webb (2015) were employed to answer the research questions. Using Statistical Package for the Social Sciences software (SPSS version 24), it was discovered that the participants used a medium level of frequency of Vocabulary Learning Strategies with Determination strategy most preferred by them. In addition, it was found that their affixes knowledge was low with multi, re-, inter- , dis-, -ful, and-er respectively considered as the order of their affixes acquisition. With respect to their interrelatedness, the overall participants' Vocabulary Learning Strategies significantly contribute to their knowledge of affixes. However, unlike Memory strategy, Determination strategy proved to have no significant contributions to their affixes knowledge.
\end{abstract}

(C) 2019 JLLS and the Authors - Published by JLLS.

Keywords: Affixes; affixes knowledge; Vocabulary Learning Strategies

\section{Introduction}

It cannot be argued that vocabulary plays a fundamental role in helping students to communicate both in spoken and in written form. As stated by Nation (2006), a vocabulary size of 8,000-9,000 words may be necessary for understanding written texts, and a vocabulary size of 5,000-6,000 words is needed for oral comprehension. In relation to Indonesian high school context, it was found that the texts of National Examination as a standardized test for Senior High School is at 4000 words level containing 2000 basic words (Aziez, 2011). Nurweni and Read (1999) added that Indonesia English curriculum set the target that a senior high school student is expected to have 4000 words after finishing his study at high school to help him easily manage some English textbooks in university. In other words, learners

\footnotetext{
* Corresponding author. Tel.: +62-821-770-661-67

E-mail address: noprianto.eko@student.upi.edu
} 
with a vocabulary below these levels might later have trouble in understanding written or spoken texts. Nurweni and Read (1999) also found that, on average, the first year students of university in Indonesia had only some knowledge of 1226 English words, a figure that seems to fall far short of the 3000-5000 word range that is widely considered the threshold level for independent reading of unsimplified texts.

Therefore, it is important for students to have sufficient vocabulary although it should be borne in mind that having sufficient vocabulary knowledge does not necessarily mean that all else is easy since vocabulary knowledge is only one component of language skills (Schmitt, 1997). Besides, it should be understood that having vocabulary knowledge means that learners should also know other types of vocabulary knowledge such as knowledge of affixes, vocabulary size, and words association knowledge which are considered to have strong relationship among them (Danilovic, Savic, \& Dimitrijevic, 2013; Mochizuki \& Aizawa, 2000; Schmitt \& Meara, 1997). This means that a person's knowledge of affixes, for instance, would probably help to increase both his/her vocabulary size and words association knowledge. This is supported by Nation (2001) stating that knowing a word means knowing the member of the family of the word and by developing proficiency, the number of the members of this word family will also increase. Knowledge of affixes itself is considered to be an important aspect of vocabulary knowledge because it helps learners read material containing unfamiliar words and expand their vocabulary, particularly their knowledge of derivatives. It contributes to determining how well a learner reads new words since an affixes can be attached to many different words and change their meaning and part of speech of word stems in a systematic ways (Mochizuki \& Aizawa, 2000).

Given how important it is to have vocabulary knowledge for communication, studies were conducted to know the process of vocabulary acquisition and found that the process in learning the vocabulary is triggered by various factors including not only explicit and implicit techniques or individual and groupbased activities but also motivation and vocabulary learning strategies (Coady in Coady \& Huckin, 1997; Nation \& Newton 1997). To be specific, the attention on Vocabulary Learning Strategies as a part of language learning strategies (LLS) Nation (2001) has grown significantly for years believing that vocabulary learning can be improved when learner's attention is led to vocabulary strategies (Coady \& Huckin, 1997; Oxford, 1990). Besides, Vocabulary Learning Strategies also enable learners to take more control of their own learning so that students can take more responsibility for their studies. However, a deep explanation on how Vocabulary Learning Strategies relate to vocabulary knowledge especially in its certain aspects such as learner's knowledge of affixes, their vocabulary size, and words association has not been explored enough (Nosidlak, 2013).

Some research to find their relationship with vocabulary size focusing on EFL undergraduate and graduate students was conducted by Ali \& Kalajahi (2012); Hamzah, Kafipour, \& Abdullah (2009); and Kirmızı (2014). All those studies seemed to reveal almost similar results showing that some categories of Vocabulary Learning Strategies contribute significantly to the students' vocabulary size despite their different level of significance. Knowing those empirical findings from those previous studies exploring the correlation between students' vocabulary learning strategies with their vocabulary size, the researcher assumed that those strategies could probably also contribute to the students' knowledge of affixes.

Therefore, considering the little attention on how Vocabulary Learning Strategies correlate with vocabulary knowledge particularly knowledge of affixes, the researcher was interested in figuring out what vocabulary learning strategies were frequently used by Indonesian high school students as well as to assessing their knowledge of affixes. The present research was also aimed at exploring how their reported vocabulary learning strategies use relate to their knowledge of affixes. After conducting the study, it is expected that these findings would make some meaningful contributions to teaching English as foreign language field particularly Indonesian. From theoretical perspectives, this current study is hoped to enrich present literatures related to the vocabulary learning strategies and knowledge of affixes. 
The findings might also be used by English teachers as a reference to design an effective way in the process of learning and teaching English considering students' vocabulary preferred learning strategy and to give more attention on students' vocabulary mastery. Lastly, for the stakeholders as the ones who become the authority, the findings could be used as valuable information to design a curriculum which takes into account students' vocabulary preferred learning strategies and focuses on how to make up for students' lack of vocabulary knowledge particularly affixes knowledge.

\subsection{Literature review}

\subsubsection{Vocabulary Learning Strategy}

In general, Vocabulary Learning strategies are considered to be a sub-group of general language learning strategies (LLS) in foreign language pedagogy which have been receiving much attention since the late 1970s (Oxford, 1990; Nation, 2001). They are defined broadly as the actions which are taken by language learners in order to foster vocabulary learning in the target language (T1lfarlıoğlu \& Bozgeyik, 2012). This definition has rooted from what Schmitt's (1997) thought that vocabulary learning strategies are fundamental to affect vocabulary learning which is seen as the process by which information is obtained, stored, retrieved and used by learners. The emergence of the strategies are also on the basis that language learners need to be helped to improve the way they go about learning vocabulary and the ability to develop their own Vocabulary Learning Strategies would become 'a powerful approach' in vocabulary acquisition (Cunningsworth in Ali \& Kalajahi, 2012).

In addition, Hamzah et al. (2009) stated that Vocabulary Learning Strategies can possibly be seen from at least three different perspectives. Firstly, they can be considered as any actions taken by learners to aid the process of learning vocabulary meaning that whenever a learner learns vocabulary, he uses strategies of doing it. Secondly, they might be seen to be related to only such actions which improve the efficiency of vocabulary learning. In other words, a learner might employ a strategy although it cannot enhance the process of learning, as done by poor learners, for instance. Lastly, Vocabulary Learning Strategies might be considered as the conscious actions done by a learner to study the meaning of new words. However. It should be noted that a learner should be encouraged to realize that he could freely and consciously choose what strategies which are the most appropriate and effective for them in the process of vocabulary learning.

Although it is already stated by Griffiths (2003) that there is no such a thing called best method nor best teacher in learning since the only one who can actually do learning is the students themselves, the students need to be given understanding that they need to try to improve their own knowledge without always being spoon-fed by the teachers. Considering this, the encouragement on the learner centeredness for the success of students in the process of learning gets more attention recently. Vocabulary Learning Strategies then should be considered as things which could help students take more control of the students' own learning so that they can improve their responsibility for their studies. It is also believed that with the help of Vocabulary Learning Strategies, a large amount of vocabulary could be acquired (Nation, 2001). To support this, Ranalli (2003) added that independence in vocabulary learning is not only beneficial in practical but also in psychological condition of the learners, so they can recall the words more effectively since they decide what to learn by themselves. Moreover, Vocabulary Learning Strategies are also equipped with a range of different strategies so that the students could decide how exactly they would deal with unknown words.

However, learners might not be able to implement Vocabulary Learning Strategies on their own and they should be trained and encouraged to use and to acquire new vocabularies by themselves (Cameron, 2001; Schmitt, 2000). This is supported by Ranalli (2003) who said that a good knowledge of the strategies and the ability to apply them in appropriate situations will considerably help students simplify 
the process of learning of new vocabularies. Therefore, it is important to set the strategy training to be involved in a vocabulary development program where teachers could possibly introduce a variety of Vocabulary Learning Strategies to the students so that they could decide which strategies would probably be best suitable for them in learning vocabulary.

With respect to Vocabulary Learning Strategies classification, many language researchers have tried to develop Vocabulary Learning Strategies taxonomy such as Schmitt (1997), Kudo (1999), and Nation (2001) which were rooted from the LLS taxonomy created by Oxford (1990). Overall, Schmitt's (1997) taxonomy which would be used in the present study, suggests two basic dimensions of Vocabulary Learning Strategies namely Discovery and Consolidation strategies.

Discovery strategies are the strategies which are used to discover the meaning of the unknown words when they are encountered for the first time. This type of strategies was broken down into two subcategories namely determination and social strategies. Schmitt (1997) explained that whenever students find it difficult to understand the words, they should be able to discover their meaning by guessing from the context, using reference materials such as dictionary, or structuring the knowledge of language. According to Schmitt (1997), determination strategies are used when learners should determine the meaning of new words without being helped by somebody else. However, if those strategies fail to help, another way to know the meaning of new words is by doing social strategies such as asking someone to help them discover the meaning of the words. Generally, the position of the helper is often the teacher in the classroom who can be asked to give help in some ways such as giving direct translation, giving a synonym, paraphrasing, using the words into sentences, etc. In addition, in discovering the meaning of a word, language learners could also do cooperative learning in which they can learn and practice the new words with others in group.

On the other side, Consolidation strategies refer to the strategies which are helpful to store and remember the meaning of the words and also aspects of the words such as their pronunciation, spelling, etc. (Schmitt, 1997). To be specific, Consolidation strategies include Memory strategy, Cognitive strategies, and Metacognitive strategies. Memory strategies were traditionally known as Mnemonics strategies which are used to relate the words with some previously learned knowledge by using some imagery form or grouping (Riankamol, 2008). Meanwhile, although they seem similar to memory strategies in many aspects, Cognitive strategies are not focused on manipulative mental process (Schmitt, 1997). They refer to the strategies used by the learners by doing repetition of the words through writing and or saying them aloud or silently, using words cards, and making word list. The last sub category of consolidation strategies from Schmitt's taxonomy is Metacognitive strategies. These strategies deal with how language learners manage their own vocabulary development and its assessment through various tools like vocabulary test. In other words, these strategies require the students to control and evaluate their own learning by overviewing the process of learning vocabulary in general.

\subsubsection{Affixes knowledge}

In relation to affixes knowledge, it has been long considered as the aspects of vocabulary knowledge which play a significant role in vocabulary development (Schmitt \& Meara, 1997; Mochizuki \& Aizawa, 2000; Nation, 2001; Sasao, 2013; Sasao \& Webb, 2015). Most researchers believe that there are three main ways in which language learners increase their vocabulary, one of which is by gaining control of prefixes, suffixes, and other word building devices together with intentionally learning or being taught and learning by meeting in context (Nation, 2001).

According to Bauer in Sasao \& Webb (2015), an affix deals with a bound morpheme which co-occurs with bases containing free morphemes. Un- which means 'not', for instance, is seen as an affix since it must be attached to a free morpheme such as happy to make a word. While -nge, on the other hand, 
cannot be seen as an affix because it attaches to a bound morpheme such as ora to form orange. Talking about knowledge of affixes is just like what Nation (2001) said about knowledge of a word that having knowledge of affixes must be seen to also have knowledge of its form, its meaning, and its use at the most general level. Knowledge of affixes form deals with the ability of the learners to identify spoken and written affixes forms while knowledge of meaning focuses on the ability to understand the meaning of the word. Knowledge of affixes use, on the other side, refers to the learners' ability to recognize its syntactic carried by affixes (Sasao, 2013). Those three components were later included and measured in the test when the researcher found out the participants' knowledge of affixes. According to Sasao \& Webb (2015), measuring three aspects of affixes knowledge is critical for diagnosing learners' weaknesses and improving their ability to learn words so that teachers may have a manageable number of affixes to teach as well as could help them deliver the feedbacks on different affixes components.

\subsection{Research questions}

Under the aforementioned circumstances, three research questions are addressed, as follows:

1. What vocabulary learning strategies are frequently used by Indonesian high school students?

2. How are Indonesian high school students' knowledge of affixes?

3. Are there any correlations between students' reported vocabulary learning strategies use with their knowledge of affixes?

\section{Method}

\subsection{Participants}

Since the present study was intended to find the relationship between Vocabulary Learning Strategies used by the learners with their affixes knowledge, a correlational research was conducted. This study involved 116 participants who were from the first grade of senior high school consisting of $27(23.3 \%)$ males and $89(76.7 \%)$ females aged between fourteen and seventeen years old.

\subsection{Instruments}

To determine participant's vocabulary learning strategies, a questionnaire of vocabulary learning strategies adapted from Schmitt's (1997) Vocabulary Learning Strategies taxonomy was distributed. The questionnaire consisted of two parts. The first part of the questionnaire was background information part which was intended to collect data on demographic variables such as age and sex of the participants while the second part was intended to collect data on VLS use of the participants. In the second part of the questionnaire, the participants were asked about how often they used the strategy items using a Likert scale of 1 to 5 to reveal the frequency of strategy that the participants use with 1 representing never used, 2 for rarely used, 3 for sometimes used, 4 for usually used, and 5 for always used.

After completing the VLS questionnaire, the participants were given The Word Part Levels Test (WPLT) proposed by Sasao \& Webb (2015) to measure written receptive knowledge of Affixes. In order to comprehensively measure their knowledge, it was designed in three sections. The first section measures knowledge of affixes forms. The second section measures knowledge of affixes meanings and the last section measures knowledge of affixes use (grammatical function). The test instrument consists of 40 items of affixes form, 34 items of affixes meaning, and 13 items of affixes use. 


\subsection{Data collection and analysis}

With respect to the data analysis, the completed VLS questionnaire and VPLT of the participants were calculated using Statistical Package for the Social Sciences software (SPSS version 24). To answer first research question, descriptive statistics including minimum score, maximum score, mean and standard deviation was employed to see how frequently the participants use the strategies. The level of frequency is considered high if the mean score is above 3.5 and is considered low if the mean score is below 2.4 while the score ranging between the two means is seen as at medium level (Oxford, 1990; Schmitt, 1997). Meanwhile, to see how good the participants' knowledge of affixes is, $60 \%$ of correct answers is set as the minimum cut-off for satisfactory affixes knowledge for each section of VPLT. Lastly, to answer how the strategies used correlate to the participants' knowledge of affixes, the Pearson Product Moment correlation was implemented with VLS as the independent variable and Knowledge of Affixes in three forms (affixes form, affixes meaning, and affixes uses) as the dependent variable.

\section{Results}

\subsection{EFL Students' Vocabulary Learning Strategies}

As presented in table 1 below, it illustrates that the overall reported frequency mean of VLS use was considered on the medium level (mean: 2.68, SD: 1.13). It can also be seen that Determination strategies were reportedly frequently used by the participants (mean: 3.1, SD: 1.2) followed by Social Strategy (mean: 2.90, SD: 1.12). Meanwhile, the lowest strategy used by the participants was Cognitive Strategy (mean: 2.34, SD: 1.13).

Table 1. Vocabulary Learning Strategies of the Participants

\begin{tabular}{llllll}
\hline Strategies & Minimum & Maximum & Mean & $\begin{array}{l}\text { Std. } \\
\text { Deviation }\end{array}$ & Category \\
& & & & & \\
\hline Determination Strategy & 1.00 & 5.00 & 3.1006 & 1.22186 & Medium \\
Social Strategy & 1.00 & 5.00 & 2.9094 & 1.12655 & Medium \\
Metacognitive Strategy & 1.00 & 5.00 & 2.5345 & 1.13569 & Medium \\
Memory Strategy & 1.00 & 5.00 & 2.5280 & 1.17160 & Medium \\
Cognitive Strategy & 1.00 & 5.00 & 2.3491 & 1.13572 & Low \\
All Strategies & & & 2.6843 & & \\
\hline
\end{tabular}

When the strategies were broken into specific aspects (Table 2), the participants prefered asking their classmates for finding the meaning of the new words as their strategy most frequently which belongs to Social strategy (mean: 3.63, SD: 1.11) followed by using a bilingual dictionary to help them translate English words into Bahasa Indonesia (Determination strategy) as their frequent strategy use (mean: 3.56, SD: 1.09). Three least strategies frequently used were recording vocabulary from English soundtrack movies in my notebook (Cognitive strategy) (mean: 1.81, SD: 1.23), using on-line exercise to test my vocabulary knowledge (Metacognitive) (Mean: 1.78, SD: 1.08), and making vocabulary cards and take them with me wherever I go (Cognitive strategy) (Mean: 1.52, SD: 0.80) respectively. 
Table 2. Rank order of the most and least frequently used strategies Strategy

\begin{tabular}{|c|c|c|c|}
\hline Strategies & Mean & $\begin{array}{c}\text { Std. } \\
\text { Deviation }\end{array}$ & $\begin{array}{l}\text { Strategy } \\
\text { use level }\end{array}$ \\
\hline I ask my classmate for meaning (SOC) & 3.6379 & 1.11431 & High \\
\hline $\begin{array}{l}\text { I use a bilingual dictionary to help me translate English words } \\
\text { into Bahasa Indonesia (DET) }\end{array}$ & 3.5690 & 1.09722 & High \\
\hline I listen to English songs and news (MET) & 3.2845 & 1.18546 & Medium \\
\hline $\begin{array}{l}\text { When I try to remember a word, I write or say it repeatedly } \\
\text { (COG) }\end{array}$ & 3.2328 & 1.27421 & Medium \\
\hline $\begin{array}{l}\text { I use pictures illustrated in the textbook to find the word } \\
\text { meanings (DET) }\end{array}$ & 2.9483 & 1.28432 & Medium \\
\hline I study a spelling of new words (MEM) & 2.8707 & 1.24782 & Medium \\
\hline $\begin{array}{l}\text { I ask the teacher to translate the words into Bahasa Indonesia } \\
\text { (SOC) }\end{array}$ & 2.8448 & 1.13140 & Medium \\
\hline I repeatedly practice new words (COG) & 2.8190 & 1.22722 & Medium \\
\hline $\begin{array}{l}\text { I ask the teacher to put an unknown word into a sentence to help } \\
\text { me understand the word meaning (SOC) }\end{array}$ & 2.7931 & 1.12302 & Medium \\
\hline I learn meaning of words by identifying its part of speech (DET) & 2.7845 & 1.28406 & Medium \\
\hline I write & 2.4397 & 1.13665 & Low \\
\hline I speak words ou & 2.4310 & 1.04027 & Low \\
\hline I use physical actions when learning words (MEM) & 2.3707 & 1.26168 & Low \\
\hline I practice English in group work activities (SOC) & 2.3621 & 1.13748 & Low \\
\hline $\begin{array}{l}\text { I record vocabulary from English soundtrack movies in my } \\
\text { notebook (COG) }\end{array}$ & 1.8190 & 1.23429 & Low \\
\hline I use on-line exercise to test my vocabulary knowledge (MET) & & 1.08593 & Low \\
\hline $\begin{array}{l}\text { I make vocabulary cards and take them with me wherever I go } \\
\text { (COG) }\end{array}$ & 1.5259 & .80716 & Low \\
\hline
\end{tabular}

\subsection{Affixes Knowledge of the ELT Students}

Table 3 reveals that the overall mean of students' affixes knowledge was 43.41 (SD: 20.02) which is below the cutoff score (60). It means that the students' knowledge of affixes is low. With respect to the knowledge of affixes parts, it could be seen that the scores of the students' affixes Form knowledge were varied ranging from 5.26 to 97.37 with the mean was 51.45 (SD: 21.65) while their knowledge of affixes Meaning mean was 49.42 (SD: 19.09). On the other side, their knowledge of affixes Use mean was only 29.38 (SD: 19.34) with the lowest score was 0 and the highest score was 84.62. Interestingly, from the data above, it showed that knowledge of one affix part did not necessarily mean that they share the same knowledge of other part of affixes knowledge. In other words, some students might have high score in affixes form yet they have low score on affixes meaning and or affixes use and vice versa, some might know the meaning of certain affixes but they fail to discover the use of them. 
Table 3. Affixes Knowledge of the participants

\begin{tabular}{lrrrrr}
\hline & Minimum & \multicolumn{1}{c}{ Maximum } & \multicolumn{1}{c}{ Mean } & Std. Deviation & Category \\
\hline Knowledge of Affixes Form & 5.26 & 97.37 & 51.45 & 21.65 & Low \\
Knowledge of Affixes & 5.88 & 85.29 & 49.42 & 19.09 & Low \\
Meaning & & & & & \\
Knowledge of Affixes use & 0 & 84.62 & 29.38 & 19.34 & Low \\
General Knowledge of & & & 43.41 & 20.02 & Low \\
Affixes & & & & & \\
\hline
\end{tabular}

In addition to those information, the researcher found it important to see also the order of accuracy of the students' knowledge of affixes to see what affixes which were known by majority of the students.

Table 4. Affixes Knowledge order of accuracy

\begin{tabular}{lrrr}
\hline No & Affixes Form & Affixes Meaning & \multicolumn{1}{c}{ Affixes Use } \\
\hline 1. & Multi- $(79.31 \%)$ & -ess $(81.03 \%)$ & $-y(63.79 \%)$ \\
2. & Re- $(75.86 \%)$ & - ese $(74.14 \%)$ & $-f u l l$ \\
& & & $(53.45 \%)$ \\
3. & Inter- $(70.69 \%)$ & - an $(74.14 \%)$ & - ly $(50.86 \%)$ \\
4. & Dis- $(68.1 \%)$ & Semi- $(71.55 \%)$ & \\
5. & $-f u l(68.1 \%)$ & $-i s t(71.55 \%)$ & \\
6. & $-e r(68.1 \%)$ & $-e r(69.83 \%)$ & \\
\hline
\end{tabular}

Table 4 illustrates that the affixes Form multi was correctly known by $79.31 \%$ students followed by re- $(75.86 \%)$, inter- $(70.69 \%)$, dis- $(68.1 \%)$, -ful (68.1\%), and -er $(68.1 \%)$ respectively. However, in the form of Affixes Meaning, the affixes - ess was correctly answered by $81.03 \%$ students followed by -ese (74.14\%), -an (74.14\%), Semi- (71.55\%), -ist (71.55\%), and -er (69.83\%) respectively. Meanwhile, in the form of Affixes Use, there were no affixes correctly answered by majority of the students. The most correctly answered affixes were $-y$ with only $63.79 \%$, followed by - full $(53.45 \%)$, $l y(50.86 \%)$, and the rests were below $50 \%$. This indicates that majority of the students had problems in identifying the use of each affixes.

\section{3. . Correlation between Students' Vocabulary Learning Strategies and their knowledge of affixes}

Table 5 illustrates the correlation between students' vocabulary learning strategies and their knowledge of affixes. As seen from the table, the correlation between overall strategies and the students' affixes knowledge was significant at 0.001 two tailed Alpha probability $(\rho<\alpha)$ with positive direction. It was also found that students' Vocabulary Learning Strategies correlate significantly with their knowledge of affixes form and meaning at 0.005 two tailed Alpha probability $(\rho<\alpha)$. However, there is no correlation of Vocabulary Learning Strategies with participants' affixes knowledge in the form of its use. However, when the strategies were broken into categories, it reveals that only memory strategy which correlates significantly with students' affixes knowledge at 0.001 two tailed Alpha probability ( $\rho$ $<\alpha)$ as well as with affixes Form, Meaning, and Use. Meanwhile, the other categories such as Determination strategy, Social Strategy, Cognitive Strategy, and Metacognitive Strategy showed insignificant correlations with students' knowledge of affixes. 
Table 5. Correlations between the VLS and Affixes Knowledge of the Students

\begin{tabular}{|c|c|c|c|c|c|}
\hline & & $\begin{array}{l}\text { Knowledge of } \\
\text { Affixes Form }\end{array}$ & $\begin{array}{c}\text { Knowledge } \\
\text { of Affixes } \\
\text { Use }\end{array}$ & $\begin{array}{c}\text { Knowledge of } \\
\text { Affixes } \\
\text { Meaning } \\
\end{array}$ & $\begin{array}{c}\text { Knowledge } \\
\text { of Affixes }\end{array}$ \\
\hline \multirow{3}{*}{$\begin{array}{l}\text { Determination } \\
\text { Strategy }\end{array}$} & Pearson Correlation & 0.026 & 0.161 & 0.009 & 0.078 \\
\hline & Sig. (2-tailed) & 0.778 & 0.085 & 0.923 & 0.408 \\
\hline & $\mathrm{N}$ & 116 & 116 & 116 & 116 \\
\hline \multirow{3}{*}{ Social Strategy } & Pearson Correlation & 0.142 & -0.078 & $.322^{* * *}$ & 0.155 \\
\hline & Sig. (2-tailed) & 0.129 & 0.403 & 0.000 & 0.096 \\
\hline & $\mathrm{N}$ & 116 & 116 & 116 & 116 \\
\hline \multirow{3}{*}{ Memory Strategy } & Pearson Correlation & $.273^{* *}$ & $.202^{*}$ & $.281^{* *}$ & $.306^{* *}$ \\
\hline & Sig. (2-tailed) & 0.003 & 0.029 & 0.002 & 0.001 \\
\hline & $\mathrm{N}$ & 116 & 116 & 116 & 116 \\
\hline \multirow{3}{*}{ Cognitive Strategy } & Pearson Correlation & 0.167 & 0.123 & 0.069 & 0.147 \\
\hline & Sig. (2-tailed) & 0.073 & 0.190 & 0.462 & 0.115 \\
\hline & $\mathrm{N}$ & 116 & 116 & 116 & 116 \\
\hline \multirow{3}{*}{$\begin{array}{l}\text { Metacognitive } \\
\text { Strategy }\end{array}$} & Pearson Correlation & 0.150 & 0.151 & 0.062 & 0.148 \\
\hline & Sig. (2-tailed) & 0.109 & 0.107 & 0.507 & 0.114 \\
\hline & $\mathrm{N}$ & 116 & 116 & 116 & 116 \\
\hline Overall & Pearson Correlation & $.231^{*}$ & 0.182 & $.218^{*}$ & $.255^{* *}$ \\
\hline Vocabulary & Sig. (2-tailed) & 0.013 & 0.051 & 0.019 & 0.006 \\
\hline Learning Strategy & $\mathrm{N}$ & 116 & 116 & 116 & 116 \\
\hline
\end{tabular}

\section{Discussion}

In relation to the first research question in which the researcher tried to reveal what vocabulary learning strategies which were frequently used by Indonesian high school students, it was found that Determination and social strategies were two most frequently used strategies with medium level of frequency. Using strategy in medium level shows that the students realized how important the strategies are yet they need to be encouraged to use them more in vocabulary learning (Oxford, 1990). This finding was in line to what other research findings that Determination strategies were more preferred by EFL learners and were in the medium frequency (Asgari \& Bin Mustapha, 2010; Çelik \& Toptaş, 2010; Hamzah et al., 2009; T1lfarlıoğlu \& Bozgeyik's, 2012) which means that most of these strategies used by participants in this study demand only a low level mental processing where participants seem to rely on strategies which mostly require rehearsal and meaning determinations without any type of deep processing. This is not surprising since the participants involved in the present study were still at the first grade of senior high school who seem to rely so much on the help of resources such as bilingual dictionary, pictures, teacher, and their classmates.

It can be seen from the data that the students used determination strategies in the form of using $a$ bilingual dictionary to help me translate English words into Bahasa Indonesia highly frequently (table 2). The use of bilingual dictionary as their main reference to cope with unknown words has been long considered as one of effective strategies in vocabulary learning (Ranalli, 2003). Besides the easiness of using it, bilingual dictionary provides them meaning of the words, pronunciation, spelling and part of the speech, and how the words are arranged into a sentence. In addition, it seems that they relied much on the help of their classmates and their English teacher to help them understand the meaning of the new words. Strategies such as I ask my classmate for meaning, I ask the teacher to translate the words into Bahasa Indonesia, and I ask the teacher to put an unknown word into a sentence to help me understand 
the word meaning as their most frequently used respectively under social strategies. Asking unknown words from classmates is preferred the most frequently because they probably feel comfortable asking and talking about everything without feeling bashful compared to asking from the teacher which become their second preference after classmates. The role of the teachers as the one who could help them in learning vocabulary is central remembering that they could be a resources, a tutor, prompter, controller, and performer as well for the learners (Harmer (2007). However, giving the students chances to learn and to find the meaning of the unknown words without direct translation by the teacher should also be taken into account. The teachers could help them by giving a synonym, paraphrasing, using the words into sentences, etc. to make them take more control on their own learning so that they could be more autonomous. As stated by O'Dell in Ranalli (2003) that training learners to become more independent is one of useful things the teachers can do with students during vocabulary learning course.

With respect to the second research question, it was found that their affixes knowledge was far below the minimum standard score of affixes knowledge. Although some students indicated that they have more affixes knowledge than others, few of them could be said to have mastered the whole affixes lists. The score might be lower than the result of the study of Mochizuki \& Aizawa (2000) and Danilovic et al. (2013) involving Japanese and Serbian learners. This finding might not be surprising since the participants of the study were beginner EFL learners with a short history of learning English ranging from three years to four years starting from three years in junior high school. Besides, the limited exposure on the affixes teaching in the classroom might influence the result of the test in which Indonesian curriculum give very little attention on direct teaching of vocabulary particularly affixes teaching.

In addition to their level of affixes knowledge, the data also indicates that knowing one part of affixes does not necessarily mean that they have good knowledge in other affixes parts. It can be seen from the data that some students showed their good knowledge on affixes form but they could not determine their meanings as well as their use. In other words, it was found that they seem to be more familiar with the form but not the meaning and the use. Some students, for instance, knew that -able looked familiar to them but they could not understand its meaning when it was combined to other free morpheme predict for instance, and they could not also decide whether it functioned as Adjectives, Adverb, Verb, or Noun. This could probably happen because they have ever found some affixes when they were reading some English text books and listening them from teachers, songs or movies without trying to figure out what they actually mean and function. That was probably supported by lack of teacher's attention on helping them use those words. However, identifying their knowledge of affixes in three parts might be helpful for English teachers to see it as a thorough diagnostics for their students' weaknesses in learning affixes so that they can design teaching process focusing on the students' weaknesses.

The present study also interestingly revealed affixes order of acquisition among Indonesian high school students (table. 4). It could be seen that the affixes multi, re-, inter-, dis-, -ful, and -er respectively become the most correctly answered by the participants. Despite the difficulty of extrapolating from the data and the need of deep exploration on it, this result of order of acquisition was concluded based on the assumption that those affixes have appeared in all parts of affixes knowledge test and was based on how many students answered those affixes correctly. Therefore, the difficulty order in which the researcher found might be considered as order of acquisition. Mochizuki \& Aizawa (2000) stated that order of affixes acquisition could possibly be derived from how many students answer the words correctly. However, factors which might contribute to the order of affixes acquisition was something which should be empirically dig further especially in Indonesian context. According to Mochizuki \& Aizawa (2000), there are five possible causes of students' knowledge of affixes acquisition such as loan words, instruction, frequency of affixes, frequency of words that contain particular affixes, and the polyfunctional nature of affixes. 
One important thing worth noting is the interrelatedness between participants' vocabulary learning strategies with their knowledge of affixes. The data showed that there was found a significant correlation with a positive direction between the overall strategies used by the participants with their knowledge of affixes. Moreover, it can also be seen that the strategies were significantly related to two parts of affixes knowledge namely affixes Form and affixes Meaning. However, when the researcher tried to figure out the relationship between determination strategy and Social strategies as Indonesian high school students' reported vocabulary learning strategies use with their knowledge of affixes, it was found that they did not show any significant correlation except for the memory strategy which was interestingly the second lowest frequent strategy use after cognitive strategies. They contributed significantly to the participants' knowledge of all affixes parts: Form, Meaning, and Use.

These interesting findings attract further question on why determination strategy could not contribute to the participants' knowledge of affixes while memory strategies which were the fourth most frequently used by the participants significantly correlate to their knowledge of affixes. This could probably happen because memory strategies such as writing a new word in a sentence, studying a spelling of new words, using physical actions when learning words, speaking words out loud when studying, etc. need a manipulative mental process which discovery strategies such as determination and social strategies do not. This supports Nation (2001) who stated that Memory strategies include some useful steps resulting in deeper processing of words which could lead to the longer storage in mind. Schmitt (1997) also added that in memory strategy, person could explicitly study the spelling and pronunciation of the words or visualize the orthographical form of the words so that the words can easily be remembered. According to Al-Seghayer (2001), the contribution of visual stimuli in memory strategies to vocabulary learning can also be attributed to specific process which relates the human beings verbal system to their imagery systems in minds. He added that by doing words translation simultaneously using verbal and visual presentation, the target words would be longer stored in mind. Besides using imagery tools, memory strategies employ semantic mapping in which teachers can use some keywords from the material the students read and also some related words with the target words which could help learners easily understand the words (T1lfarlıoğlu \& Bozgeyik, 2012).

In relation to the determination strategy, its insignificant correlation with participants' knowledge of affixes could probably be seen because their awareness of using those strategies such as the use of bilingual dictionaries (the second highest frequently used) are not followed by more practices on how to use the words in communication both orally and in written form. Besides their probable problem on how to use resources like dictionary appropriately, the use of not good dictionary might also contribute to the insignificant correlation. As stated by Schmitt (1997) that a good dictionary should contain a complete information related to the words such as grammar, usage status, synonym discrimination, and its distinction to the spoken and written use to help the learners fully understand the words. In other words, it could be said that determination strategy can only be helpful in recognizing the meaning of unknown words without helping the students remembering them in a long term memory.

\section{Conclusions}

To sum up, this present study discovered that the participants used a wide variety of Vocabulary Learning Strategies with medium frequency with Determination strategy which was most preferred by them. This study also showed that using bilingual dictionary under determination strategy and asking their classmates for the meaning of unknown words under social strategy were the only two strategies which were categorized as high frequently used. In addition, the current research diagnosed the students' knowledge of affixes and found that their affixes knowledge was low with affixes multi, re-, inter-, dis- 
, -ful, and -er respectively became the most correctly answered by majority of the participants. In term of their interrelatedness, the overall participants' Vocabulary Learning Strategies significantly contribute to their knowledge of affixes. In term of Vocabulary Learning Strategies categories, Memory strategy did have significant correlation with students' affixes knowledge in three affixes parts. Determination strategy, on the other hand, as their most preferred strategy, could not be seen to have any significant contributions to their affixes knowledge.

Considering the results of this study, the researcher acknowledges that this current study might not be able to be seen as a broad information for all students in Indonesia since it focused only on one high school with the same level students. It might also interesting to involve all levels of high school students in many different schools to see their Vocabulary Learning Strategies choice patterns and to see their differences in future research. Moreover, the rationales behind their vocabulary learning strategies choice and their knowledge of affixes acquisition might not be thoroughly explained since the data was taken only quantitatively. With the use of qualitative methodology, the further research might be able to triangulate the results to cope those uncovered questions. Eventually, this current study seemed only to deal with how students' vocabulary learning strategies could contribute to the improvement of students' affixes knowledge. How the contribution of those strategies with students' affixes knowledge need to be dug further. As for teacher, the need to create an effective teaching which considers students' Vocabulary Learning Strategies preference is critical as well as to give more attention and emphasize on students' vocabulary knowledge development in the form affixes knowledge through, for instance, direct teaching on affixes which is considered limited.

\section{References}

Al-Seghayer, K. (2001). The effect of multimedia annotation modes on L2 vocabulary acquisition: A comparative study. Language Learning \& Technology, 5(1), 202-232. Retrieved from http://lt.msu.edu/vol5num1/alseghayer/.

Ali, S., \& Kalajahi, R. (2012). Vocabulary learning strategies and vocabulary size of ELT students at EMU in Northern Cyprus. English Language Teaching, 5(4), 138-149. https://doi.org/10.5539/elt.v5n4p138.

Asgari, A., \& Bin Mustapha, G. (2010). The type of vocabulary learning strategies used by ESL students in University Putra Malaysia. English Language Teaching, 4(2), 84-90. https://doi.org/10.5539/elt.v4n2p84.

Aziez, F. (2011). Examining the vocabulary levels of Indonesia's English national examination texts. Asian EFL Journal, 51(April), 16-29. Retrieved from http://70.40.196.162/PTA/April-2011Aziez.pdf.

Cameron, L. (2001). Teaching languages to young learners. Cambridge: Cambridge University Press.

Çelik, S., \& Toptaş, V. (2010). Vocabulary learning strategy use of Turkish EFL learners. Procedia Social and Behavioral Sciences, 3, 62-71. https://doi.org/10.1016/j.sbspro.2010.07.013.

Coady, J., \& Huckin, T. (1997). Second language vocabulary acquisition: A rationale for pedagogy. Annual Review of Applied Linguistics. Cambridge: Cambridge University Press. Retrieved from http://catdir.loc.gov/catdir/samples/cam034/96003115.pdf. 
Danilovic, J., Savic, J. D., \& Dimitrijevic, M. (2013). Affixes acquisition order in Serbian EFL learners. Versita, 10(1). https://doi.org/10.2478/rjes-2013-0006.

Griffiths, C. (2003). Language learning strategy use and proficiency: The relationship between patterns of reported language learning strategy $(L L S)$ use by speakers of other languages (SOL) and proficiency with implications for the teaching/learning situation (Doctoral thesis, University of Auckland). Retrieved from http://researchspace.auckland.ac.nz.

Hamzah, M. S. G., Kafipour, R., \& Abdullah, S. K. (2009). Vocabulary learning strategies of Iranian undergraduate EFL students and its relation to their vocabulary size. European Journal of Social Sciences, 11(1), 39-50. Retrieved from https://www.researchgate.net/publication/228801062_Vocabulary_Learning_Strategies_of_Iranian _Undergraduate_EFL_Students_and_its_Relation_to_their_Vocabulary_Size.

Harmer, J. (2007). The practice of English language teaching. Malaysia: Pearson Education Limited.

Kirmızı, O. (2014). Measuring vocabulary learning strategy use of Turkish EFL learners in relation to academic success and vocabulary size. World Journal of Education, 4(6), 16-25. https://doi.org/10.5430/wje.v4n6p16.

Kudo, Y. (1999). L2 vocabulary learning strategies. Honolulu: University of Hawai'i. Retrieved from http://www.lll.hawaii.edu/nflrc/networks/nw14.

Mochizuki, M., \& Aizawa, K. (2000). An affixes acquisition order for EFL learners : An exploratory study. System, 28(2), 291-304. https://doi.org/10.1016/S0346-251X(00)00013-0.

Nation, I. S. P. (2001). Learning vocabulary in another language. Cambridge: Cambridge University Press.

Nation, I. S. P. (2006). How large a vocabulary is needed for reading and listening? The Canadian Modern Language Review, 63(1), 59-82. https://doi.org/10.1353/cml.2006.0049.

Nation, P., \& Newton, J. (1997). Teaching vocabulary. In J. Coady \& T. Huckin (Ed.), Second language vocabulary acquisition (pp. 238-254). New York: Cambridge University Press.

Nosidlak, K. M. (2013). Vocabulary learning strategies of the advanced students. Journal of Language Teaching and Research, 4(4), 655-661. https://doi.org/10.4304/jltr.4.4.655-661.

Nurweni, A., \& Read, J. (1999). The English vocabulary knowledge of Indonesian university students. English for Specific Purposes, 18(2), 161-175. https://doi.org/10.1016/S0889-4906(98)00005-2.

Oxford, R. (1990). Language learning strategies: What every teacher should know. New York: Newbury House.

Ranalli, J. M. (2003). The treatment of key vocabulary learning strategies in current ELT coursebooks (Doctoral thesis, University of Bimingham, UK). Retrieved from https://www.researchgate.net/publication/237796163_THE_TREATMENT_OF_KEY_VOCABU LARY_LEARNING_STRATEGIES_IN_CURRENT_ELT_COURSEBOOKS_REPETITION_RE SOURCE_USE_RECORDING.

Riankamol, N. (2008). A survey study of vocabulary learning strategies of gifted English students at Triam Udomsuksa School in the first semester of academic year 2008 (Master thesis, Thammasat University, Bangkok). Retrieved from http://litu.tu.ac.th/2012/images/litu/Research/student/2551/4921032217.pdf. 
Sasao, Y. (2013). Diagnostic tests of English vocabulary learning proficiency: Guessing from context and knowledge of word parts (Doctoral thesis, Victoria University of Wellington, Wellington). Retrieved from http://researcharchive.vuw.ac.nz/xmlui/bitstream/handle/10063/4475/thesis.pdf?sequence=2.

Sasao, Y., \& Webb, S. (2015). The word part levels test. Language Teaching Research, 21(1), 12-30. https://doi.org/10.1177/1362168815586083.

Schmitt, N. (1997). Vocabulary learning strategies. In N. Schmitt \& M. McCarthy (Ed.), Vocabulary: Description, acquisition and pedagogy (pp. 199-277). Cambridge: Cambridge University Press.

Schmitt, N. (2000). Vocabulary in language teaching. Cambridge: Cambridge University Press.

Schmitt, N., \& Meara, P. (1997). Researching vocabulary through a word knowledge framework: Word associations and verbal suffixes. Studies in SLA, 19(1), 17-36. Retrieved from https://www.cambridge.org/core/journals/studies-in-second-languageacquisition/article/researching-vocabulary-through-a-word-knowledgeframework/B66BDCC37C142B6C4AE1E5F134A67FA6.

Tilfarlığlu, F. F. Y., \& Bozgeyik, Y. (2012). The relationship between vocabulary learning strategies and vocabulary proficiency of English language learners. Journal of Applied Linguistics \& English Literature, 1(2), 91-101. https://doi.org/10.7575/ijalel.v.1n.2p.91.

\section{İngilizceyi yabancı dil olarak öğrencilerinin kelime öğrenme stratejileri ve ekleri bilgisi}

\section{$\ddot{O} \mathbf{z}$}

Kelime Öğrenme Stratejileri ve eklerinin bilgisinin uzun süredir, öğrencilerin kelime öğrenmelerini etkilediği düşünülmektedir. Ancak, birbirleriyle ilişkileri çok az dikkat çekmiş görünüyor. Bu güncel çalışma, Endonezya lise öğrencilerinin kullandığı kelime öğrenme stratejilerinin sıklığını araştırmak, eklerin bilgilerini öğrenmek ve rapor edilen kelime öğrenme stratejilerinin nasıl kullanıldıklarını öğrenmek için ekler hakkındaki bilgileri ortaya koymak amacıyla yapıldı. Bu korelasyon çalışması, on dört ve on yedi yaşları arasındaki 27 erkek ve 89 kadından oluşan lise birinci sınıfta okuyan 116 katılımcıdan oluşmaktadır. Araştırma sorularını yanıtlamak için Schmitt (1997) 'den uyarlanan Kelime Öğrenme Stratejileri anketi ve Sasao \& Webb (2015) tarafindan önerilen bir Kelime Kısmi Seviye Testi kullanılmıştır. Veriler Sosyal Bilimler yazılımı için İstatistik Paketi (SPSS sürüm 24) kullanıllarak analiz edilmişt.r Katılımcıların en çok Belirleme stratejisi ile Orta Düzeyde Kelime Öğrenme Stratejileri kullandıkları tespit edildi. Ek olarak, eklerinin bilgisinin sırasıyla eklerinin edinim sırası olarak kabul edilen sırasıyla low with multi, re-, inter- , dis-, -ful, and -er şeklinde olduğu tespit edilmiştir. Birbirleriyle olan ilişkileriyle ilgili olarak, genel katılımcıların Kelime Öğrenme Stratejileri, eklerine ilişkin bilgilerinde önemli bir katkı sağlar. Ancak, Bellek stratejisinden farklı olarak, Belirleme stratejisinin, eklerinin bilgisine önemli bir katkısı olmadığını kanıtladı.

\section{AUTHOR BIODATA}

Eko Noprianto is an English teacher at state senior high school 1 Kibang, Lampung, Indonesia and received his master degree from Universitas Pendidikan Indonesia majoring English education. His research interests include character education, language learning strategy, and Systemic Functional Linguistics. 